\title{
Introduction: Postcolonial Nostalgia and the Threads of Empires
}

\author{
Giusi Russo \\ Guest Editor
}

In his influential 1989 essay titled "Imperialist Nostalgia" anthropologist Renato Rosaldo declares his "anger at recent films that portray the empire with nostalgia"-identifying the "enthusiastic reception" of Heat and Dust, A Passage to India (1984), Out of Africa (1985) and The Gods Must Be Crazy as the source of his ire (Rosaldo 107). Nostalgia, as the old graffito has it, may not be what it used to be, but thirty years after Rosaldo's broadside, similar products still occupy plenty of space in the Western mediascape. Still peddling the longing for an imperial past, films like Victoria and Abdul, The Man Who Knew Infinity, and The Viceroy's House all share common threads with their 1980s precursors; both A Passage to India and Victoria and Abdul, for example, depict the surveillance of brown bodies in constructed British spaces suggesting, given the success of these artifacts in the West, that the insidious desire to survey the racial other persists well into the twenty-first century.

Of course, contemporary nostalgia goes beyond cinematic accounts and in fact seems to pervade contemporary society: in a 2016 article on Donald Trump's design to take America back to its white-only glory, Pulitzer Prizewinner Lynn Nottage described nostalgia as a disease; her diagnosis recalls historian Matt Matsuda's work on eighteenth-century European journeys to the Pacific in which he defines nostalgia as "a physical and mental malady, a quality of melancholy, displacement, and homesickness."

Whether or not nostalgia is a diagnosable medical condition, it is plainly resilient as a way of thinking about and representing empire and colonialism. Like the imperial project, nostalgia has gone global producing a network of expected and unexpected longings and of provocations that tend to ignore the violence of the imperial projects. The 2010 New York Times's Vietnamese tour on "Recreating French Roots," the 2015-16 British Channel 4 television series Indian Summer, and the countless advertisements for chic and glamorous tourist "safaris" demonstrate that the disease of imagining a return to the glorious colonial past is still alive and well-and economically relevant, to boot.

What inspired this volume was not just the general persistence of imperial nostalgia but the specific contradiction lurking within the imperial design 
that Rosaldo described in 1989: supposedly motivated by their "peculiar sense of mission, the white man's burden," Europeans "intentionally altered or destroyed" the cultures they colonized, but later bemoaned the passing of those very cultures. In Rosaldo's opinion, "imperialist nostalgia... revolves around a paradox," with the agents of colonialism "mourn[ing] the passing of what they themselves ... transformed" (Rosaldo 108). The essays in this volume duly analyze contemporary versions of this paradox.

If the current state of the world is responsible for the continued wave of nostalgic renditions of the imperial past, this historical context has been producing multiple accounts of how the colonial past still hinges on the national and transnational present. In the wake of decolonization and the collapse of the old Cold War global order, contemporary migrations, geopolitics, and challenging assimilations make the memory of empires divisive and problematic at best. If the modern post-imperial nation wants to be secular and pluralist it should recognize a past that damaged a substantial portion of its population. There is a moral reckoning to be made for what colonial administrations did, along with acknowledgments that the skewed economic processes put in place by imperialism not only benefitted the home-nations during the time of empire, but have continued to do so ever since.

The questions we posed in our call for papers centered on the relationship between the longed-for past and the conditions of the present that shape the memory of empires. Moreover, we were interested in who remembers what, and with what outcome. When we first conceived of this special issue, the electoral rhetoric in Europe and the United States was recalling a past of rigid hierarchies such as the imperial one which threatened the struggle for contemporary minorities and endangered even further the multicultural western project. It was evident in the run-ups to the Brexit referendum of June 2016 and the American presidential election of November that year, that postcolonial nostalgia had emerged forcefully in the Anglophone public sphere. Thus, we were fully expecting our call for papers to result in essays that addressed the specifically British longing for empire. However, in the same way that Rosaldo's essay moves away from the obvious locales of Raj and safari depicted in the movies that stoked his anger to an analysis of the much less frequently covered phenomenon of American imperialism in the Philippines, the contributors to this volume also took us to unexpected locations to give us their accounts of imperial nostalgia and postcolonial modalities of remembering. The issue follows the objects of nostalgia, from nostalgia of possibilities, of what might have been, to nostalgia of imperial actualities. The last three articles discuss the unexpectedly simultaneous presence of progressive and conservative nostalgias. As a collection, the articles thus represent a continuum of nostalgia: from longing for moments of missed possibilities such as pluralism in pre-partition India or resistance 
in colonial Korea to putting together the longing for empire under the form of political speeches and public exhibitions. Even the negative rhetoric on empires contributes to recasting it at the center of public discourse.

The analyses the contributors to this volume provide on the modalities and consequences of remembering empire provide an alternative thread to the dominant narratives of imperial history of the present. Among other things, they expose how the incoherent nuances of the past complicate historical trajectories and encourage reformulation of the relationship between countries and their imperial pasts.

Contrary to the usual suspects of postcolonial theory (Spivak et al.) who put the British and French empires at the center of their writings, the work of Svetlana Boym focuses on the Soviet collapse and changes in European borders. Boym's theoretical interpretation of contemporary modes of remembering presents us with the history of nostalgia itself, initially medical and then social and political. In Boym's words "Nostalgia (from nostos-return home, and algia-longing) is a longing for a home that no longer exists or has never existed" (Boym xiii). Boym shows us that "While the longing is universal, nostalgia can be divisive" (Boym xiii). In the case of nostalgia as part of a white supremacist nationalist project, what repairs the longing is belonging. Boym is also sympathetic towards the nostalgic who longs "for continuity in a fragmented world" (Boym xiv); his/her present desire for a constructed continuity is also irresponsible, because there is no such thing as "a guilt free homecoming" in which history is transformed into a "private or collective mythology"; the nostalgic person may desire "to revisit time like space" as if time could remain static, but there is really no responsible way to avoid "the irreversibility of time that plagues the human condition" (Boym xv).

Modernity and its variations dominate this volume. Still an elusive concept, modernity appears as a tool to create and to erase, to remember and to forget, to dismember and to unify. A number of authors elaborate on Boym's "unrealized possibilities" as the essays of Bhagat-Kennedy, Kim, and Saxena show. Kim, in particular, shows us a specific formulation of "offmodernism" which in Boym's configuration illustrates "a critique of both the modern fascination with newness and the no less modern reinvention of tradition" (Boym xvii) Some of the authors engage directly with Boym's taxonomy of nostalgia, picking up on her distinction between restorative and reflective forms:

Restorative nostalgia stresses nostos and attempts a transhistorical reconstruction. Reflective nostalgia thrives in algia, the longing itself, and delays the homecoming-wistfully, ironically, desperately. Restorative nostalgia does not think of itself as nostalgia, but rather as truth and tradition. Reflective 
nostalgia dwells on the ambivalence of human longing and belonging and does not shy away from the contradictions of modernity. Restorative nostalgia protects the absolute truth, while reflective nostalgia calls it into doubt. (Boym xviii)

Collectively, these essays complicate the notion that the age of empire ended and was succeeded by a steady process of decolonization. The contributions to this volume show a much more complex scenario in which empire is transnationally adaptive, useful to a contemporary nationalist rhetoric, and still exerting influence in global economic processes. Furthermore, these essays show that remembering, too, is a non-linear and fragmented process that goes back and forth. For instance, imperial nostalgia can manifest itself in contemporary anti-migration attitudes, which seek to reinstate the kinds of separation and segregationist policies that marked the age of empire. Ultimately, the connection between empires and national identity assumes the rationale of fascist modernities through which the glorification of the nation built proud and patriotic citizens. Such processes happened mostly through a white-ification of the national project, since the painful memory of victims of imperialism is allowed no space to establish a counter-memory.

The issue opens with two accounts of what might have been, and concludes with three accounts of what is. The authors show that there are nostalgic products that look at past possibilities of unity in the case of Indian Hindus and Muslims, and reaction to assimilation in the case of the Koreans under Japanese rule. Both accounts confirm the presence of longing for lost possibilities that in one case affect the present and in the other produce what author Andrew Kim calls "the teleology of liberation." Monika BhagatKennedy's article discusses the relationship between history and national identity. She juxtaposes the physical/material/hyper-visible monument of the Taj Mahal and its invisibility in contemporary Hindu nationalist discourse with Ahmed Ali's 1939 novel Twilight in Delhi and Ali's nostalgia for the lost possibility of unity between Hindus and Muslims. The British Empire is present in this work in the form of divider of local forces and as a tool of Hindu nationalist ideology. According to Bhaghat-Kennedy, Twilight longs for what true pluralism might have been through the narration of a lost Delhi center of Muslim ashraf, a memory lost today. Bhaghat-Kennedy's essay inaugurates the traumatic thread of this volume. For her, both past and present are traumatic because of the violent acts of erasing Muslims from the Indian nation's design. More authors in this volume discuss how the colonial state's erasure of minorities was part of colonial modernity. Twilight as literary monumentalization aids the Taj Mahal/monument to reclaim its place in India's past and, therefore, in its present, too. 
Dealing with erasing colonial modernities and the nostalgia of what might have been is also what drives Andrew Kim's essay on 2016 Korean movie The Handmaiden. According to Kim, the movie's suggestive reconstruction of colonial Korea provides a tool to look back at the "options available to Korea" before the forced Japanese process of assimilation. Koreans went from subservient colonial peoples to "imperial subjects," and the movie tells us a story of what alternatives might have existed at the climax of colonialism. Kim presents us with a scenario of two women who are both victims and perpetrators of the imperial order of things. They are victims because of the patriarchal component in imperial modernities, but they are also able to rise above victimhood because they subvert the sexual order by defeating their male enemy and escaping to Shanghai together as lovers. Kim shows us how The Handmaiden entertains with a different understanding of conquering people and lands. In Kim's view even the Japanese Empire is, in its own terms, conquered by the West-specifically by England. Victorian and Edwardian narratives seem to appropriate the destiny of the two female protagonists of The Handmaiden. The Korean male protagonist of the film is nostalgic of precolonial Japan but simultaneously assumes the role of the colonizer in order to defraud a Japanese woman. Kim, therefore, shows us that intrinsic to colonial modernity are both modernities and anachronisms as well as a disruption and blending of patriarchal and colonial orders.

After these tales of possibilities, the issue follows the actualities of empires not just by analyzing the trauma of empire but also by recasting the British as architects of fractures that weakened the postcolonial state. Vandana Saxena takes us to the lost unity of precolonial and colonial struggle in mid-twentieth-century Malaya. Saxena, similarly to Bhagat-Kennedy, discusses a novel in order to show the relationship between trauma and nostalgia. In the case of Tan Twan Eng's The Garden of Evening Mists, however, Saxena focuses on Boym's theory of algia and "loss"-the kind of nostalgia that imposes forgetting of the local conflicts in the struggle for decolonization (Bhagat-Kennedy by contrast wants to find a possible precolonial unity). This nostalgic longing appears because the present circumstances prompt characters to look back rather than forward. Saxena tells us about the multiple, ethnically varied anti-colonial forces that contributed to the foundation of the Malaysian nation, including the Chinese community (alas always accused by the Malays of being loyal only to China) and an anti-British Dutch farmer who calls his farm "Majuba" in honor of the Boer victory. The British imperial politics here too are responsible for undermining the possibility for future pluralism of the postcolonial state; the British claimed that the legitimacy of British power was founded on the myth of the "primacy of the Malay community in Malaya." Saxena instead presents a nostalgic 
scenario in which multiple groups-the Malay, the Chinese, and even the Japanese-participated in the anti-colonial struggle. The protagonist of The Garden of Evening Mists is the embodiment of trauma and nostalgia, arising from her own betrayal and collaboration with the Japanese, and manifesting in her building a Japanese garden that is both a celebration of past happiness and a mourning for lost love. However, Saxena encourages us not to heal in the postcolonial sphere but to recover: the difference between healing and recovering lies in the presence of memory, in the process of recovering, and the conflictual memory of the protagonist stays intact. By paying attention to the ambivalently-situated tea-planter Magnus, who has named his plantation Majuba in memory of his Boer ancestors' victory over the British in the 1880s, Saxena adds a transnational angle that points to the mobility of nostalgia. Himself a settler-colonist in an imperial locale, Magnus's longing for his own Boer identity prompts a thoroughly transnational understanding of nostalgia.

Following on from Saxena's essay, Erica Lombard's essay shows the extent to which postcolonial nations' attempts at autonomous definition may still be compromised by external forces. In the publication and marketing of Lisa Fugard's Skinner's Drift Lombard analyzes what happens when the nostalgic person longing for a South African "home" is not South African, but based elsewhere. Lombard's essay presents us with a dual layer of nostalgia, one present in the novel itself, and one in the readers of the novel in a US setting. The protagonist of Skinner's Drift longs for a lost past, the immediate post-apartheid (after 1994), a lost home, and a lost season of life. Lombard complicates the national narrative of nostalgia and the traditional colonizer/colonized dichotomy, however. In her essay the worst nostalgic is the American who from his/her armchair longs for a constructed and prepackaged South Africa that is both progressive (because of its claim to have "ended" apartheid) but also conservative in its metonymic use as an historical and timeless "Africa" drawn in traditional imperialist terms: wild, strongly colored, and difficult to tame. Lombard accurately demonstrates that the appeal to the American audience is specific to the historical moment of the book's publication, the Bush era, when liberal Americans were seeking to evade the kind of globalization that aimed at "greed, revenge, and religious polarization." Along with this dark globalization came a neoimperial understanding of war and the overall American fascination with the frontier. One might argue also that "armchair-nostalgia" for a lost Africa and South Africa provides American readers with a kind of comfortinviting them to explore a land supposedly different and distant from their own, whose notorious racial relations allow them to construct South Africa as the pinnacle of violence in order to absolve themselves of their own.

Two contemporary critiques of the public political and cultural spheres in the Netherlands and Britain conclude the issue to show how nostalgia 
threatens European (attempts at) multiculturalism. Continuing the thread of white innocence explored by Lombard, the essays by Saskia Pieterse and Astrid Rasch explore the political present and the relationship between contemporary national identity and the (mis)remembered imperial past. Pieterse depicts the problematic relationship the Dutch have with their colonial past, describing how, since about the 1990s, Dutch politicians and cultural institutions have searched for new definitions of old schemes, formulas that can somehow absolve Dutch colonialism from being colonial. Pieterse rightly asks whether "commercialization, capitalism and modernization were innocent undertakings." The essay illustrates different challenges to a clear/innocent imperial record as well as the relationship between economic development and the emergence of nostalgia. For example, Pieterse cites an exhibition on the Dutch golden age that fails to question slavery and instead merely includes slaves along with spices as trade commodities that fueled the mercantilist successes of eighteenth-century Holland. Pieterse effectively argues that the current nostalgia for a past Dutch splendor is also anti-Muslim because of the longing for a dominantly white and Christian nation.

Astrid Rasch's exploration of British imperial memory closes the volume. Through a variety of sources that range from political speeches and motion pictures to a historical monograph, Rasch shows how contemporary nostalgia still revolves, as Rosaldo noted in 1989, "around a paradox." Rasch's essay notes how "the celebration of empire does not happen in spite of but through an engagement with the criticism of empire." Both Pieterse and Rasch use Paul Gilroy's framework of "postcolonial melancholia" to shed light on the kinds of divisive imperial memories that exclude the experience of postcolonial European citizens. Salman Rushdie's well-known description of imperial nostalgia is also useful here in discussing recent cinematographic renditions of empire in which colonizers, even when depicted in negative terms, are still, in Rushdie's words, "the agents of the story." Rasch shows us how Britain's quest for a post-Brexit identity comes with a reelaboration of the empire through its commodification (the dominant present of political speeches and cultural artifacts) and a revisionist "truth" about the benefits of imperial conquests. Rasch claims that parallel to the emergence of postcolonial nostalgic products, public intellectuals search for a meaning of the imperial past that aims to transcend political polarizations. In moments of national crises of identity the left (anti-empire) and the right (pro-empire) lose credibility. David Lean, for instance, whose 1984 version of A Passage to India was one of the film's prompting Rosaldo's original formulations regarding imperial nostalgia, claimed his film portrayed an understanding of empire that transcends leftist or rightist arbitrary interpretations. Similarly, the contemporary historian Nigel Ferguson declares himself as a "brave fighter against the unthinking dogma." 
In conclusion, this special issue shows how the present complicates the modalities of nostalgia disrupting the linear directions Rosaldo described in the late 1980s. One aspect that emerges here is that decolonization has not taken a clear and straightforward path either in actual history or in historiographical and literary representations thereof. The authors of this volume seem to suggest that to this day the empire has a central and foundational role in the independent nation-state that emerged through anti-colonial struggle. Such influence is not only present in the immediate historical moment of the proclamation of the new postcolonial entity but continues as a permanent distorted mirror of the dialectics of empires. Such conflicts or dialectics, the authors show, are present not only in the original colony/mother land places but also elsewhere because the memory of empire is powerful enough to create new configurations that transcend the original colonizer and colonized.

\section{Works Cited}

Boym, Svetlana. The Future of Nostalgia. Basic Books, 2008.

Lindt, Naomi, "In Vietnam, Recreating French Roots. The New York Times." 18 May 2010, https://www.nytimes.com/2010/05/19/greathomesanddestinations /19gh-vietnam.html. Accessed 10 September 2019.

Smith, David “'Nostalgia is a Disease Many White Americans Have."” Interview with Lynn Nottage, The Guardian, 17 February 2016, https://www.theguardian .com/stage/2016/feb/17/lynn-nottage-sweat-donald-trump-bernie-sanders. Accessed 10 September 2019.

Rosaldo, Renato. Culture \& Truth: The Remaking of Social Analysis. Beacon Press, 1989. 